\title{
ЕВОЛЮЦІЯ ТА СПЕЦИФІКА ВЗАЕМОДІЇ ДУХОВНОГО ТА ІНТЕЛЕКТУАЛЬНОГО РОЗВИТКУ В ПРОЦЕСІ НАУКОВОГО ТА НАВЧАЛЬНОГО ПІЗНАННЯ В ЧАСИ АНТИЧНОСТІ ТА РАННЬОГО СЕРЕДНЬОВІЧЧЯ
}

\author{
О. В. Юрченко
}

\author{
Викладач ХНПУ імені Г. С. Сковороди
}

\begin{abstract}
Учення про людину, iii духовно-інтелектуальні якості, їх зв'язок із процесом розвитку пізнання є одними 3 ключових питань багатьох гуманітарних наук. Протягом усієї історії людства до питань духовного розвитку була звернена творчість видатних учених і філософів. Сучасні науковці М. Пірен та В. Ребкало зазначають: «Духовність - категорія людського буття, якою виражається людська здатність до самоствердження та творення культури... Духовність - соціально-моральна цінність, глибинна основа культури, прояву людського в людині, основна цінність демократичного суспільства, всі сфери якого мають бути проникнуті сутністю духовного: гуманізмом, повагою до людини, толерантністю тощо» [1, с. 228].

Сьогодні ми маємо величезну кількість праць, які спрямовані на виявлення закономірностей становлення духовно-інтелектуального світу людини. Сучасний педагог не може успішно розвивати духовно-інтелектуальні риси тих, кого навчає, без знання загальнотеоретичних закономірностей становлення цих якостей, без свідомого використання тих напрацювань, які виробила наукова думка.

Методологічні основи становлення духовної культури розглянуті у роботах філософів (Платон, Сократ, Фома Аквінський, І. Г. Гердер, О. Гумбольт, І. Кант, Г. Гегель, К. Маркс тощо), у тому числі представників української філософської думки (Г. С. Сковорода, П. Д. Юркевич, М. В. Гоголь, С. С. Гогоцький, В. К. Винниченко, В. П. Андрущенко, Н. І. Горлач тощо). Різні аспекти проблеми духовно-інтелектуального навчання і виховання духовності знайшли своє відображення у працях великих педагогів минулого (К. Н. Вентцель, Я. А. Коменський, М. Монтессорі, І. Г. Песталоцці, М. І. Пирогов, К. Д. Ушинський, В. О. Сухомлинський, А. С. Макаренко, Р. Штайнер, Ш. О. Амонашвілі тощо).

Як свідчить аналіз наукової літератури, вітчизняні науковці В. Андрющенко, В. Сухомлинський, В. Дудик, В. Баранівський, М. Савчин та інші визначають структуру і компоненти духовної і інтелектуальної сфер, виокремлюють ряд складових, що впливають на формування духовності, виявляють моральні і інтелектуальні цінності, виділяють духовні та інтелектуальні потреби людини. Сучасні вчені також підіймають питання встановлення гармонії між науковим пізнанням, інтелектуальними досягненнями людства і моральністю. У педагогічній літературі основна увага приділяється формуванню поняття духовності у православній, традиційній та гуманістичній педагогіці XIX-XX ст.
\end{abstract}

Зазначимо, що недостатньо уваги приділено розвитку уявлення про поняття духовно-інтелектуального пізнання в часи античності та раннього середньовіччя.

У сучасних психолого-педагогічних дослідженнях підкреслюється, що категорія «духовність» відноситься до розряду філософських. Тому загальнотеоретичні питання формування духовно-інтелектуальних якостей людини у процесі пізнання потрібно розглядати, спираючись на їх філософський аспект.

Видатний сучасний філософ В. П. Андрющенко зазначає, що поняття духовного, духовності завжди мали у філософії фундаментальне значення. Як у соціальних науках, так і в педагогіці, вони виступають визначальними в проблемах розуміння сутності людини, її призначення у світі, сутнісних характеристиках суспільства. Філософ виділяє її інтегруючу, системотворчу функцію у формуванні цілісного світу особистості: «дух, духовність співвідносяться з морально забарвленими інтелектуально-вольовими якостями особистості і охоплюють сфери свідомості, мислення і діяльності в їх єдності, причому ні одна зі сфер сама по собі не розкриває в повній мірі феномен духовності» [2, с. 367].

В свою чергу, М. Пірен та В. Ребкало у роботі «Духовність особистості - основна цінність демократичного суспільства» зазначають: «Духовність, моральність — це той рівень розвитку особистості й суспільства, який є консолідуючою засадою, здатною об'єднати людей; це сила, що покликана стимулювати національне відродження України, забезпечити громадянський мир і злагоду в суспільстві» [1, с. 229].

Поняття духу, душі, духовного виникли ще в первісній культурі, як показав відомий дослідник цієї культури Е. Б. Тайлор. На його думку, первісні люди, замислюючись про такі явища, як сновидіння або смерть, прийшли до розуміння того, що кожна людина має деяку особливу субстанція — душу, яка може покидати свою тілесну оболонку тимчасово або назавжди [3]. Пояснюючи зміст поняття «дух» у різних народів, учений побачив його коріння в таких словах, як «сердце», «дихання», «подув». Е. Б. Тайлор, користуючись багатим етнографічним і історичним матеріалом, проілюстрував поширення на земному шарі анімізму як системи 
уявлень про існування духовного начала у людини, тварини, рослини, одухотворення сил і явищ природи, а також показав його еволюцію у часі.

Антична натурфілософія дала початок антропоцентризму, де вперше були відокремлені поняття духовного та інтелектуального. Давньогрецька філософія зароджувалась як потужний інтелектуальний рух до знання в його найбільш всеохоплюючій теоретичній формі [4, с. 27]. Разом з тим, еліністична філософія вперше проголосила принцип: знання саме по собі не має цінності, воно потрібно, оскільки вчить нас правильно жити, відмовляючись від тих моральних якостей, які дають негативні наслідки. Філософія як учення про мудрість в особистому житті інтерпретується як інтелектуальна терапія. Так, Епікур казав: «порожні слова того філософа, якими не лікується ніяке страждання людини. Як від медицини нема ніякої користі, якщо вона не виганяє хвороби з тіла, так і від філософії, якщо вона не виганяє хвороби душі» [4, с. 26].

Сократ, що стояв біля витоків погляду на людину як на центр Всесвіту, головним у людині вважав розум і внутрішній моральний закон. Центральними проблемами у філософії для нього стали етичні і гносеологічні, причому останні доповнювали етику. Під духовністю Сократ розумів поєднання розумової активності і моральності. Аристотель показав, що Сократ досліджував моральні доброчесності і перший намагався дати їх загальні визначення $[5,6]$. Духовне у нього сполучається з інтелектуальним, особистість повинна сповідувати гуманні принципи і норми поведінки людей по відношенню як один до одного, так і до суспільства. Такі духовні поняття як справедливість, законність, добро, зло філософ застосовував до аналізу існуючого суспільного ладу і викривав його вади. Головне положення «сократівського інтелектуалізму» - доброчесність завжди є знанням, порок - неуцтвом. Таким чином, моральні якості людини, iї цінності він прагнув обгрунтовувати з позицій раціональності.

До Сократа загальновизнаним було усвідомлення необхідності наближатися до формування однієї з чеснот, зокрема, або справедливості, або чесності, або стриманості, або мудрості тощо. Сократ же вперше підкреслив необхідність поєднання усіх позитивних моральних якостей особистості і об' єднання їх у понятті «духовність», розвиток якої повинен стати основою вдосконалення людини: «чесноти суть те, що робить краще природу особи, вочевидь, що чесноти стають формою пізнання, призначення яких - вдосконалювати душу і розум» [7, c. 103]. Філософ справедливо вважав, що головна задача вихователя — навчити людей зрощувати душу.

Сучасні італійські історики філософії Д. Антисері, Дж. Реале, досліджуючи філософію античності, наводять висловлювання учених про значимість сократівського розуміння духовного: «Завдяки цьому відкриттю, Сократ створив моральну та інтелектуальну традицію, яка живить Свропу по наш час» [7, с. 101]. «Слово «душа», завдяки потокам, які проникли крізь глиб віків, звучить завжди з етичним і релігійним відтінком... Цей піднесений сенс слово набуло вперше в устах і проповідях Сократа» [7, с. 101]. Таким чином, Сократ глибоко розкрив сферу духовного як самостійну реальність, наголосив на необхідності виховувати духовність, вказав на взаємозв’язок між духовністю та інтелектом.

Платон також присвятив одну з важливих частин своєї філософії проблемі духовності та інтелекту. Він прийшов до духовної першооснови усього сущого, яка пронизує усі сфери буття [8, с. 101]. Платон розумів шлях пізнання через поняття, через ідею, яка є первісним здобутком душі [8, с. 132]. Душа, згідно Платону, має таку структуру, яка включає розум, волю, прагнення. Духовне зростання, осягнення першопринципів, на думку філософа, є складним процесом: «Пізнання таких речей не підлягає передачі, як інші знання; тільки в процесі спільного життя, після довгих суперечок, подібно іскрі, яка спалахнула, народжується душа, яка сама себе розуміє... Таким речам навчаються лише спільно, осягають істину і неправду, що знаходяться в основі реальності, після довгої і досконалої перевірки...» [7, с. 137]. Із поняттям духовного Платон зв’язував соціальну справедливість, яка може встановитися в суспільстві тоді, коли духовність буде в душі кожної людини. Філософ увійшов в історію як мислитель, який вперше на цій основі розробив ідеал держави [9].

Центральною ідеєю певних творів Платона є ідея блага, або вищого добра, яке є джерелом єдності усіх чеснот. Лише під проводом ідеї блага знання стає придатним та корисним. Процес розумового освоєння світу з часом стане процесом морального перетворення [7, с. 154]. Без ідеї блага усі людські знання, навіть найбільш повні, були б зовсім непотрібними [9, с. 311]. Доброчесність в тому і полягає, що зі світу ілюзій ми поступово потрапляємо у світ істинний [7, с. 154].

Підсумовуючи погляди Платона на проблематику духовного і інтелектуального, підкреслимо, що за найбільш високу мету душа розумна ставить вищі цінності, благо людей і справедливість. 3 цього випливає діяльнісний підхід філософа до світу: «одна з основних настанов, залишених нам Платоном, провіщає про те, що... найголовнішим є трансформація дійсності».

Аристотель першим у філософії висунув ідею нероздільності духовного і тілесного. У трактаті «Про душу» філософ визначив це поняття так: «Слід вважати душу суттєвою формою фізичного тіла, що має життя в потенції, а субстанція як форма є ентелехія. Душа, отже, є перша ентелехія фізичного тіла, що потенціально володіє життям» [7, с. 209]. Під ентелехією Аристотель розумів цілеспрямованість як рушійну силу, активне 
начало, яке перетворює можливість у дійсність. У роботі «Велика етика» філософ підкреслював: «Ми живемо ні чим іншим, як душею» [10, с. 301].

Джерелом знання філософом було визначено організм як цілісність тілесного і духовного, причому управлянні тіла душею є «життєво-творчим» [6, с. 249]. Активно діючий розум, за Аристотелем, знаходиться у душі: «будь-яка душа, яка рухається тілом в тому чи іншому напрямку, має свій власний ейдос (ідею), який Аристотель називає Розумом, так що душа, за Аристотелем, є енергією Розуму» [6, с. 250]. Людська душа містить у собі три частини, зокрема, вегетативну, чуттєву і раціональну, що відображує зростання ступенів буття. Піднімаючись по цим ступеням, розумова душа людини стає кульмінацією розвитку її первинних ступенів. Душа приводить особистість у стан руху: «душа трактується у Аристотеля як організуючий, управляючий і навіть керуючий принцип» [6, с. 248].

На думку філософа, мислення людини концентрує форми, які містяться в образах, і виділяє їх у вигляді культивованого поняття [7, с. 21]. Аристотель вважав, що раціональний вибір вказує на наявність розумової здатності душі, в свою чергу, раціональна здатність душі надає особливу цінність людині [7, с. 211], розум $\epsilon$ «першодвигуном, абсолютною закономірністю буття» [6, с. 254].

Розуміння взаємозв' язку інтелектуального, розумового і духовного, морального пізнання відбилося в арістотелевому поділі наук. У роботі «Метафізика» він писав про те, що наука спирається на «теоретиче знання, яке $\epsilon$ мудрістю і полягає у відшуковуванні першопричин і начал» $[11$, с. 26]. Філософ поділив науки на теоретичні, практичні і творчі, - перші ведуть пошук заради знання як такого, другі пізнають заради морального удосконалення, треті $є$ прикладними. Вищим розумом для Аристотеля є такий, що має характер діяльнісного, створюючого.

У роботі «Велика етика» філософ стверджував, що пізнання світу за допомогою наук має на меті досягнення блага і $\epsilon$ духовною категорією: «Слід звернути увагу на те, що у будь-якої науки і уміння є деяка мета, і ця мета є завжди деяким благом: ні одна наука, ні одне уміння не існують заради зла... Отже, наша справа говорити про благо в суспільному, політичному житті» [10, 297]. Благо людини, на думку Аристотеля, полягає в діяльнісній роботі душі і розуму, згодних з доброчесністю. Вище благо він вважав досконалою метою. Доброчесність, в свою чергу, він поділяв на розумову і моральну [7, с. 237]. Філософ убачав в розумовій чесноті здатність «доводити до досконалості те, благом чого вона є» [7, с. 233], а під моральними чеснотами розумів «моральні звичаї поведінки» [7, с. 233].

На думку Аристотеля, душа потребує особливої опіки, а вдосконалення особистості - єдина гідна мета у житті [7, с. 213]. На цьому шляху особливу роль філософ відводив наставнику, вихователю: «Наставників у кожній справі ми поціновуємо більше, вважаємо, що вони знають більше, ніж ремісники, що вони мудріше, бо знають причини того, що створюється... Наставники мудріше..., в силу того, що вони озброєні концептуальним знанням причин» [7, с. 226]. У роботі «Нікомахова етика» Аристотель зазначав, що «універсально доброчесна людина освічена всебічно» [7, с. 236], крім того, «доброчесний повинен бути добре вихований, його треба привчити до доброго» $[10,289]$. Філософ стверджував, що на виховання і навчання повинна бути звернена як «приватна увага», так і суспільна [10, с. 290] та державна увага [10, с. 289].

Підсумовуючи погляди Аристотеля на проблему духовно-інтелектуального пізнання, підкреслимо, що філософ наголошував на необхідності поєднання цих компонент у процесі пізнання дійсності: «Принципи розсудливості узгоджуються із моральними чеснотами» [10, с. 284], а «пізнання душі може дати багато нового для усякої істини, головним чином, для пізнання природи».

Отже, античність залишила надзвичайно широкий спектр різноманітних філософських концепцій. Філософські теорії, створені в античності, назавжди залишилися прикладами і зразками для наступних епох. В аспекті нашого дослідження підкреслимо, що в ці часи пізнання стало необхідним процесом і основою для осягнення істини. Позиція античності була інтелектуалістичною [12], це означало те, що в усіх областях життя і культури основою для неї була думка. Разом з тим, досягнення в теорії пізнання сполучалися з розвитком етики як вчення про мораль, її принципи і роль у суспільстві.

Після занепаду античної культури пройшло декілька століть політичного неспокою і інтелектуального занепаду, після чого склалася християнська філософія, що мала зовсім інший характер. Домінуючим напрямком середньовічної філософії стала схоластика, що мала цілком релігійний характер. Яскравою особливістю цього світогляду було те, що світ не мав самостійного значення по відношенню до Бога. Теорію пізнання філософи-схоласти розуміли як теоретичне тлумачення церковного віровчення за допомогою формальних логічних аргументів. Відомий дослідник середньовічної філософії В. Татаркевич вважає, що не можна говорити про занепад філософії у середні віки [12]. В теорії пізнання розглядалися питання розмежування знання і віри, аналізу природи знання, розмежування видів знання, знаходження основ і критеріїв знання, дослідження інтуїтивного знання; задачею духовного виховання було виховання християнського благочестя. 
Розвитку розумових здібностей людини в рамках середньовічної культури сприяла енциклопедична традиція, яка склалася ще в античну епоху. Примітно те, що енциклопедична література була придатна до освітніх потреб. Так, у творі філософа Кассіодора «Настанови в науках божественних і світських» обгрунтовувалась необхідність інтелектуальної деяльності як складової частини християнської культури, при чому умовою ії поширення стала загальна освіта [13, с. 347].

Метою теологічних викладів було прагнення науково і систематично розкрити і витлумачити порядок світобудови, демонструючи його досконалість та засвідчуючи велич божественного задуму. Таким чином, «пізнання природного світу також опиняється внутрішньо співвіднесеним з духовним планом людського буття, проте не сполучено прямо, а пов'язано опосередковано; воно отримує автономію в рамках цього зв'язку» [13, с. 348].

Розглянемо погляди на співвідношення духовного і інтелектуального в процесі пізнання найвпливовішого схоласта Фоми Аквінського, який створив логічну, струнку і енциклопедично універсальну систему християнської теології і філософії. Він провів чітку межу між вірою і знанням, причому розум, на його думку, може дати лише обгрунтування несуперечливості положень безпосереднього волевиявлення Творця. Проте із цих ідеалістичних позицій він зробив вагомий внесок у питання співвідношення духовного і інтелектуального в пізнанні. Людина, на думку філософа, має раціональну природу: «Розум є наймогутнішою природою людини», і призначення людини полягає в тому, щоб розуміти і діяти з згідно з розумінням [7, с. 546]. Це положення складає основу його етики і політики. Філософ вважав, що неперебутнім у людині є розуміння благих цілей і початку дії.

Для Фоми душа, як форма тіла, з’єднана з ним [14]. Життя людини розумілося ним як основа і «матерія» для вищого, духовного життя, яке розвивається під церковним покровом. Для душі відкритий шлях раціонального пізнання, яке здійснюється в результаті взаємодії почуттів і інтелекту [14]. Шлях пізнання, як вважав філософ, починається з утворення у душі чуттєвих образів, які подібні об'єктам, що пізнаються. У своїй головній роботі «Сума теології», яка справила найзначніший вплив на християнський світ, Фома Аквінський зазначав: «По закону своєї природи людина приходить до осягнення за допомогою розуму через чуттєве, бо усе наше пізнання бере свій початок у чуттєвому сприйнятті» [7, с. 560]. 3 цих чуттєвих образів інтелект абстрагує універсалії, як структурні характеристики, що відбивають закономірності системи світобудови. На його думку, інтелект керується принципами, що вже існують в душі, проте формуються тільки в процесі чуттєвого пізнання.

Раціональність людини і їі духовність Фома оригінально поєднав із розумінням закону, в якому він вбачав засіб змусити уникати злих діянь для тих, хто не робить цього за власною волею. Крім функції захисту, закон, на його думку, мав ще й педагогічну функцію. Він розрізняв такі типи законів: вічний закон, природній, людський, окрім інших і над усім - Одкровення [7, с. 547]. Вічний закон він розглядав як раціональний божественний план. У його здійсненні частково приймає участь і людина, як раціональна сутність, така участь людини у вічному законі іє законом природним. Згідно з природним законом, люди, будучи раціональними, слідують або повинні слідувати його суті, яка насичена духовністю: «Роби добро і уникай зла», дія, яка узгоджується з розумом, $\epsilon$ доброю, незгодна 3 ним - злою. Таким чином, святий Фома визначив юстицію, під якою розумів теорію справедливості як схильність душі, що дає «сталу волю знаходити для кожного своє право» [7, с. 548].

У філософському ученні про мораль Фома Аквінський виходить 3 того, що духовне заломлюється в прагненні до блага, яке можна зрозуміти тільки за допомогою інтелекту, практичний розум може 3 досвіду і з божественного закону здобути загальні принципи моралі. У аспекті нашого дослідження підкреслимо, що при визначенні активності людини в пізнанні і перетворенні оточуючої дійсності Фома Аквінський поєднував оцінку їі інтелектуальних і духовних якостей: «Міра досконалості людської дії пропорційна підпорядкуванню останньої розуму, який володіє принципами моралі» [15, с. 371].

Роджер Бэкон відомий як один $з$ провісників методології науки Нового часу. Критикуючи схоластичні методи пізнання, характерні для середньовіччя, Р. Бекон підкреслював значення наук як для досягнення істинного знання, так і для розвитку інтелектуальної сфери людини. Дослідник його творчості К.П. Виноградов стверджує, що однією з головних задач, які ставив перед собою філософ, було «теоретичне обгрунтування необхідності докорінної реформи наукових інститутів і всієї системи освіти. Р. Бекон вважав, що в університетах та інших навчальних закладах необхідне перенесення акцентів 3 філософських і метафізичних спекуляцій на точні науки і природознавство» [16].

Велике значення мали сформульовані Р. Беконом методологічні вимоги до пізнавального процесу, такі як визнання досліду як критерію істини, використання кількісного підходу при дослідженні явища або процесу, критика хибних авторитетів. На його думку, «плоди мудрості під захистом точних законів» приведуть до бажаної мети.

Розглядаючи аргументацію і експеримент як методи отримання знання, філософ підкреслював, що аргументи дають висновок, проте не позбавляють сумнівів, не дають впевненості. Теоретичний доказ, навіть довершений з логічної точки зору, потребує дослідного підтвердження. Тому істину потрібно відшукувати, користуючись експериментальним методом пізнання. Так, у відому трактаті «Великий твір про таємні діяння мистецтва та природи і нікчемності магії», в частині «Вчення про дослідну науку» філософ зазначав: «Не слід 
людині, яка не провела досліду, шукати докази, щоб спочатку набути інтелектуальне знання, бо вона не отримає докази до того, як проведе дослід»[16].

На думку Р. Бекона, дослідна наука, по-перше, служить для перевірки висновків усіх наук, по-друге, надає важливі факти іншим наукам, по-третє, самостійно досліджує таємниці природи, незалежно від інших наук. Отже,випередивши науку Нового часу, філософ зрозумів методологічне значення досліду в пізнанні.

В аспекті нашого дослідження підкреслимо, що Р. Бекон визнавав кращим методом викладання метод, який передбачає поєднання теоретичного доказу із застосуванням чуттєво-предметної діяльності того, хто навчається.

Дослід, який філософ розглядав як умову пізнання, Р. Бекон поділяв на зовнішній і внутрішній. Зовнішній дослід потрібен для чуттєвого сприйняття видимих речей, а внутрішній — для невидимого, який стосується духовної сфери. До числа ступенів внутрішнього досвіду він включив, крім суто наукових положень, духовні почуття, чесноти.

Духовність людини Р. Бекон розглядав у «моральній філософії», яка конкретизує поняття добра і зла, «переважно називається практичною, усі ж інші науки їй підпорядковані». Він бажав «показати красоту і користь наук про мораль». У згаданому трактаті «Великий твір», в розділі «Про те, як людині управляти самою собою», філософ стверджує, що проблема духовності потребує наукового підходу: «Частина моральної і громадянської науки оповідає про мораль окремої особистості, щоб у кожній розквітала краса благочестя і була покинута потворність вад» [16].

Моральна філософія, за Беконом, є «кращою і благороднішою з усіх попередніх наук». Вона поділяється на декілька гілок і включає в себе поділ на частини, одна з яких обгрунтовує поведінку по відношенню до інших людей, інша - по відношенню до самого себе.

Він погоджувався з Аристотелем у тому, що благо суспільне є обов'язковою передумовою особистого блага і запевняв: «Дійсно, любов $є$ вища доброчесність, і вона спрямована на суспільне благо, і їі супроводжують мир і справедливість...» [16]. Тому на підтримку моральних якостей людей, їх духовності, слід спрямувати і правову свідомість суспільства. Закони, які слугують впорядкуванню взаємовідношень людей, Р. Бекон вважав найбільш важливими. У трактаті «Великий твір» він присвятив розділ «Про дотримання законів державних і сімейних» питанням регулювання державою правових норм, що стосуються «ставлення людей один до одного». Держава, за переконанням філософа, як для підтримки інтелектуальних і моральних якостей громадян, розвитку їх свідомості, так і для створення суспільного блага, повинна потурбуватися про те, «щоб кожен займав деяку потрібну посаду, і щоб кожний приносив державі користь».

Отже, приєднуючись до Аристотеля, Сенеки, Боеція, Авіценни, Туллія та інших, і розвиваючи їх думки, Р. Бекон стверджував, що «благом для людини, причому єдиним у цьому житті, філософи вважають доброчесність». Підсумовуючи погляди Р. Бекона на взаємозв'язок інтелектуального і духовного, відмітимо, що він виражає свою солідарність 3 переконаннями Сократа: «Той, хто чинить лиху дію, може робити це тільки внаслідок невігластва, оскільки тоді в ньому виникає бажання скоїти гріх, він втрачає знання і розум» [16].

Дослідник творчості Р. Бекона А. С. Горєлов у нарисі «Філософія Роджера Бекона і ії місце в історії європейської культури засвідчив велику вагу інтелектуальної та духовної спадщини філософа у загальноєвропейському масштабі: «Інтуїція Бекона дозволила йому зрозуміти, в чому саме полягала односторонність сучасної йому наукової культури - університетської схоластики XIII ст., і позначити з більшою або меншою ясністю, куди слід рухатися далі. Найбільш дивовижним було те, що культура у подальшому, хоча і не відразу, почала переорієнтуватися згідно саме тим напрямкам, які визначив Роджер Бекон» [16].

Отже, античні і середньовічні учені показали духовну еволюцію людини, продемонстрували уміння доводити засобами розуму істини, які приводять до духовності, логічність цих істин, несуперечливість їх по відношенню до фундаментальних принципів розуму. Учені часів античності та раннього середньовіччя довели, що людині потрібно культивувати в собі не тільки інтелект, але і зрощувати також почуття, через які розкривається особистісне багатство і унікальність. Культивування інтелекту разом із духовними якостями, ставлення до істини як моральної цінності повинно перебувати у деякій цільності. Інтелектуальність повинна бути співвіднесена з духовністю, поєднуючись у певній гармонії.

\section{Література}

1. Пірен М., Ребкало В. Духовність особистості - основна цінність демократичного суспільства // Вісник Національної академії державного управління. Сер. Державне управління. 2011. № 2. С. 228-236.

2. Социальная философия : учебник / под общ. ред. В. П. Андрющенко, Н. И. Горлача. Киев-Харьков : Издательсткий центр «Единорог», 2002. $736 \mathrm{c}$.

3. Эдуард Бернетт Тайлор. Первобытная культура / пер. с англ. М. : Политиздат, 1989. 573 с.

4. Ойзерман Т. И. Проблемы историко-философской науки. М. : Мысль, 1969. 398 с. 
5. Аристотель. Метафизика. Переводы. Комментарии. Толкования. СПб.: Алетейя. Киев : Эльга, 2002.832 с.

6. Лосев А. Ф., Тахо-Годи А. А. Аристотель: В поисках смысла // Жизнь замечательных людей: малая серия: сер. биогр. М. : Молодая гвардия, 2014. Вып. 62. 296 [8] с., ил.

7. Д. Антисери, Дж. Реале. Западная философия от истоков до наших дней. Античность и Средневековье (1-2) / пер., ред. С. А. Мальцевой. СПб : «Издательство Пневма», 2003. 688 с.

8. Гуревич П. С. Философия человека: в 2 ч. М. : типография ИФ РАН. Ч. 1. 221 с.

9. Платон. Сочинения : в 3-х т. / под ред. А. Ф. Лосев, В. Ф. Асмус. Академия наук СССР. Институт философии. М. : Мысль, 1970. Том 3 (1). 687 с.

10. Аристотель. Сочинения: в 4-х т. / пер. с древнегреч., общ. ред. А. И. Доватура. М. : Мысль, 1983. Т. 4. 830 с. (Филос. наследие. Т. 90). В надзаг:: АН СССР. Ин-т философии.

11. Аристотель. Метафизика / пер. с греч. П. Д. Первова и В. В. Розанова. М. : Институт философии, теологии и истории св. Фомы. 2006. 232 с.

12. Татаркевич В. История философии. Античная и средневековая философия / пер. с пол. В. Н. Квасков. Пермь: издательство Пермского университета. 609 с. (Духовность / гл. ред. В. С. Дудик. К. : Европ. энцикл., 2008. Кн. 1. 688 с. (Серия «Европейская энциклопедия»).)

13. Столяров А. А. Раннее средневековье (VI-X вв.) // История философии. Запад-Россия-Восток. Кн. 1. Философия древности и средневековья. М. : Греко-латинский кабинет, 1995. С. 346-352.

14. Фома Аквинский. Сумма теологии / пер. А. В. Апполонова. Т. 2: Часть первая. Вопросы 65-119. М. : Издатель Савин С. А., 2007. 652 с.

15. Столяров А. А. Философия Фомы Аквинского / История философии. Запад-Россия-Восток. Кн. 1. Философия древности и средневековья. М. : Греко-латинский кабинет, 1995. С. 367-371.

16. Роджер Бэкон. Избранное / под общ. ред. И.В. Лупандина. М. : Издательство Францисканцев. 2005.480 с. 